\title{
ANALISIS PENGARUH MANAJEMEN MODAL KERJA, PERTUMBUHAN PENJUALAN DAN KEBIJAKAN HUTANG TERHADAP PROFITABILITAS PERUSAHAAN
}

\author{
Afriyanti Hasanah ${ }^{1 *}$, Risky Setyawan ${ }^{2)}$ \\ 1) Program Studi Akuntansi Manajerial, Politeknik Negeri Batam \\ E-mail: afriyanti@ polibatam.ac.id \\ ${ }^{2)}$ Program Studi Akuntansi Manajerial, Politeknik Negeri Batam \\ E-mail: riskysetyawannn@gmail.com
}

\begin{abstract}
This study aims to examine the effect of working capital management, sales growth and debt policy on profitability. This study uses secondary data sourced from the official website www.idx.co.id. The research data uses audited annual reports on the property and real estate sectors listed on the Indonesia Stock Exchange (BEI) for the period 2013 - 2017. Through the purposive sampling method, a sample of 100 companies was obtained. The data analysis technique in the study used multiple regression analysis using panel data. The results of this study indicate that the working capital management variable has no effect on profitability, the growth variable has an influence on profitability, and the debt policy variable shows no influence on profitability.
\end{abstract}

Keywords: Leverage, Profitabilitas,jkSales Growth, Working Capital Management

\begin{abstract}
ABSTRAK
Penelitian ini bertujuan untuk menguji pengaruh manajemen modal kerja, pertumbuhan penjualan dan kebijakan hutang terhadap profitabilitas. Penelitian ini menggunakan data sekunder yang bersumber dari laman resmi www.idx.co.id. Data penelitian menggunakan audited annual report pada perusahaan sektor properti dan real estate yang terdaftar di Bursa Efek Indonesia (BEI) periode 2013 - 2017. Melalui metode purposive sampling, diperoleh sampel sebanyak 100 perusahaan. Teknik analisis data pada penelitian ini menggunakan analisis regresi berganda dengan menggunakan data panel. Hasil penelitian ini menunjukkan variabel manajemen modal kerja tidak memiliki pengaruh terhadap profitabilitas, variabel pertumbuhan penjualan memiliki pengaruh terhadap profitabilitas, dan variabel kebijakan hutang menunjukkan tidak memiliki pengaruh terhadap profitabilitas.
\end{abstract}

Kata Kunci: Kebijakan Hutang, Manajemen Modal Kerja, Pertumbuhan Penjualan, Profitabilitas 


\section{PENDAHULUAN}

Era Globalisasi merupakan zaman dimana perusahaan dituntut agar lebih efektif dalam menjalankan suatu usahanya agar dapat bersaing dengan perusahan lainnya. Hal ini disebabkan karena tidak adanya lagi pembatas yang timbul antar negara termasuk suatu bisnis atau usaha. Salah satu indikatoriiuntuk menilai suatu perusahaan dapat terkelolai dengan ekfektif adalah bagaimana perusahaan tersebut mengelola modal kerja. Modal kerja dibutuhkan oleh perusahaan untuk membiayai aktivitas operasional perusahaan seperti pembelian bahan mentah, membiayai kebutuhan perusahaan, membayar gaji karyawan, dan kegiatan lainnya. Ketika pengelolaan manajemen modal kerja tidak sesuai dengan aturan, maka perusahaan akan mengalami kegagalan dalam mempertahankan kelangsungan hidupnya.

Ketika suatu perusahaan mengeluarkan biaya untuk kegiatan operasionalnya, secara tidak langsung perusahaan tersebut mengharapkan biaya atau uang yang dikeluarkan tersebut dapat dihasilkan kembali melalui kegiatan penjualan. Pendapatan yang masuk dari hasil penjualan akan digunakan kembali untuk membiayai kegiatan operasional berikutnya dan siklus ini akan berputar secara terus menerus setiap periode berjalannya perusahaan. Selain pengelolaan modal kerja, perusahan dapat dipengaruhi oleh faktor lain salah satunya adalah pertumbuhan penjualan. Faktor penjualan didalam perusahaan merupakan salah satu indikator penentu untuk perolehan laba pada perusahaan tersebut.

Peran modal kerja sangat berpengaruh untuk meningkatkan penjualan perusahaan, karena penjualan perusahaan harus memiliki dana guna membiayai aktiva lancar perusahaan. Mengingat pentingnya dana diperusahaan maka penggunaan dana harus dikelola secara efektif dan efiesien. Pengeluaran dan pemasukan yang terdapat dalam perusahaan akan mempengaruhi tingkat profitabilitas perusahaan.

Faktor lain yang menjadi indikator mempengaruhi profitabilitas ialah Leverage, karena leverage dapat digunakan untuk meningkatkan modal perusahaan dalam rangka meningkatkan keuntungan (Shintya, Situmorang, \& Iryani, (2017). Hasil penelitian yang dilakukan oleh Putra \& Badjra, (2015) menguji pengaruh kebijakan hutang, pertumbuhan penjualan dan ukuran perusahaan terhadap profitabilitas yang diukur dengan return on asset (ROA) pada sub sektor perusahaan industri makanan dan minuman di Bursa Efek Indonesia menggunakan 12 perusahaan sebagai sampel. Hasil penelitian menyimpulkan kebijakan hutang berpengaruh negatif signifikan terhadap profitabilitas.

Penelitian mengenai pengaruh manajemen modal kerja terhadap profitabilitas perusahaan yang diteliti oleh Santhi \& Dewi (2014) dan Bulan (2016) menemukan adanya pengaruh signifikan manajemen modal kerja terhadap profitabilitas perusahaan. Hasil lain ditemukan pada penelitian Santoso (2013), yang menyimpulkan bahwa tidak adanya pengaruh manajemen modal kerja terhadap profitabilitas.

Begitu pula dengan variabel pertumbuhan penjualan yang menemukan pengaruh yang berbeda-beda pada beberapa penelitian. Menurut Shintya, et al. (2017) pada penelitiannya menemukan adanya pengaruh pertumbuhan penjualan terhadap profitabilitas perusahaan. Hasil penelitian oleh Putra \& Badjra (2015) mengindikasikan bahwa pertumbuhan penjualan tidak memiliki pengaruh terhadap profitabilitas perusahaan.

Penelitian ini merujuk pada penelitian Ibrahim (2018) yang meneliti mengenai pengaruh manajemen modal kerja dengan menggunakan alat ukur current ratio dan quick ratio terhadap return on equity (ROE) yang mewakili variabel profitabilitas. Sampel penelitian sebanyak 4 perusahaan sektor industri di Iraq dari 
tahun 2007 - 2016. Hasil penelitian ini mengindikasikan bahwa modal kerja memiliki pengaruh positif terhadap profitabilitas perusahaan yang diproksikan dengan return on equity (ROE).

Penelitian ini dan penelitian sebelumnya memiliki beberapa perbedaan yaitu pertama, menggunakan alat ukur perputaran modal kerja yang mewakili variabel manajemen modal kerja, dengan alasan untuk melihat kemampuan perusahaan dalam memanfaatkan modal kerja dalam menghasilkan penjualan bersih. Kedua, menambahkan variabel independen pertumbuhan penjualan (sales growth), karena peneliti menduga adanya pengaruh variabel tersebut terhadap tingkat profitabilitas perusahaan. Ketiga, peneliti menggunakan return on asset (ROA) sebagai proksi pada penelitian ini dengan alasan, pengukuran dengan menggunakan aset lebih stabil dibandingkan dengan modal sendiri ataupun penjualan. Objek penelitian ini menggunakan perusahaan properti dan real estate yang terdaftar di Bursa Efek Indonesia, karena sektor tersebut dinilai memiliki peranan penting dalam menyumbang pertumbuhan perekonomian nasional dan menurut (Hasibuan, Dzulkirom AR, \& Endang NP, 2016) sektor tersebut memiliki prospek yang baik bagi investor yang ingin berinvestasi. Penelitian ini menggunakan tahun terbaru agar memperoleh hasil terkini yaitu dari tahun 2013 - 2017 .

\section{KAJIAN TEORI, LITERATUR DAN PENGEMB ANGAN HIPOTESIS}

\section{Teori Pecking Order}

Munculnya teori ini pertama kali dikemukakan oleh Donaldson pada tahun 1961 yang kemudianidisempurnakan oleh Myers pada tahun 1984. Menurut Sutapa, et al. (2008) teori iniimenjelaskan urutan prioritas para manajeridalam menentukanipendanaannya. Sejalan dengan pernyataan tersebut, Nuswandari (2013) menyebutkan urutan yang dijadikan prioritas dalam pendanaan perusahaan adalah internal fund (dana internal), debt (hutang), dan equity (ekuitas).

\section{Kajian Lite ratur}

Penelitian oleh Gunde, Murni, \& Rogi, (2017) menguji analisis pengaruh leverage terhadap profitabilitas yang di ukur dengan return on asset (ROA) pada perusahaan manufaktur sub industry food and beverages yang terdaftar di BEI (20122015). Hasilnya menyimpulkan bahwa leverage berpengaruh signifikan terhadap profitabilitas.

Martien (2016) menguji efektivitas penggunaan manajemen modal kerja dan likuiditas terhadap rentabilitas pada PT Multi Indocitra, Tbk dan entitas anak. Peneliti menggunakan proksi return on asset (ROA) untuk mewakili variabel rentabilitas. Hasil penelitian menyatakan tidak adanya pengaruh secara parsial maupun simultan antara modal kerja dan lukuiditas terhadap rentabilitas.

Penelitian oleh Sapetu, et al. (2017) menguji pengaruh manajemen modal kerja terhadap profitabilitas perusahaan yang diukur dengan return on investment (ROI). Objek penelitian tersebut pada perusahaan food and beverages yang terdaftar di BEI periode 2012-2015. Hasil penelitian menyimpulkan bahwa perputaran modal kerja memiliki pengaruh negatif signifikan terhadap profitabilitas.

Penelitian oleh Syahputra \& Ibrahim (2018) menguji pengaruh modal kerja terhadap profitabilitas. Objek penelitian adalah sektor advertising printing media yang terdaftar di BEI pada tahun 20102014. Hasil penelitian menyimpulkan bahwa hasil yang berbeda terlihat dari masing-masing alat ukur pada variabel modal kerja, seperti perputaran kas dan perputaran persediaan tidak berpengaruh terhadap profitabilitas perusahaan yang diukur dengan return on investement (ROI), sedangkan untuk perputaran piutang 
menunjukkan adanya pengaruh terhadap profitabilitas diperusahaan tersebut.

Penelitian oleh Ibrahim (2018) yang menguji pengaruh manajemen modal kerja terhadap profitabilitas pada sektor industri di Iraq tahun 2007-2016. Proksi yang digunakan untuk mewakili variabel profitabilitas ialah menggunakan return on equity (ROE). Hasil penelitian menunjukan bahwa manajemen modal kerja berpengaruh positif terhadap profitabilitas perusahaan.

\section{PENGEMB ANGAN HIPOTESIS \\ Pengaruh Manaje men Modal Kerja \\ Terhadap Profitabilitas}

Birgham dan Houston (2006) menyatakan bahwa modal kerja sangat berpengaruh terhadap keberlangsungan hidup suatu perusahaan. Modal kerja adalah investasi perusahaan pada aktiva jangka pendeknya seperti kas, sekuritas, persediaan, dan piutang.

Profitabilitas menjadi ukuran yang digunakan manajemen dalam mengendalikan modal kerja secara efisien (Sapetu, et al., 2017). Suatu perusahaan memiliki modal kerja yang tinggi maka akan memungkinkan lancarnya kegiatan operasional dalam suatu perusahaan. Manajemen modal kerja yang positif dan efektif secara tidak langsung dapat meningkatkan profitabilitas. Perusahaan. . Berdasarkan penjelasan tersebut maka hipotesis pertama pada penelitian ini adalah:

$\mathrm{H}_{1}$ : Manajemen modal kerja berpengaruh terhadap profitabilitas.

\section{Pengaruh Pertumbuhan Penjualan Terhadap Profitabilitas}

Salah satu faktor yang mempengaruhi tingkat profitabilitas perusahaan adalah pertumbuhan penjualan. Penjualan merupakan hal harus diperhatikan di suatu perusahaan, perusahaan tidak akan berjalan dengan lancar ketika strategi penjualannya tidak efektif. Semakin besar penjualan maka semakin besar profitabilitas suatu perusahan.
Hasil penelitian Shintya, et al. (2017) menunjukkan adanya pengaruh positif pertumbuhan penjualan terhadap profitabilitas, yang berpendapat bahwa semakin tinggi penjualan menunjukkan kinerja yang baik oleh perusahaan. Hasil yang sama ditemukan oleh Hasanah \&Enggariyanto (2018) yang menunjukkan hasil pertumbuhan penjualanberpengaruh terhadap return on assets. Selain itu, penelitian Chotimah \& Susilowibowo (2014) juga mengindikasikan adanya pengaruh positif pertumbuhan laba terhadap profitabilitas. Maka hipotesis kedua pada penelitian ini adalah:

$\mathrm{H}_{2}$ : Pertumbuhan penjualan berpengaruh terhadap profitabilitas.

\section{Pengaruh Kebijakan Hutang Terhadap Profitabilitas}

Leverage dapat digunakan untuk meningkatkan modal perusahaan dalam rangka meningkatkan keuntungan, oleh karena itu, leverage merupakan salah satu faktor penting yang dapat mempengaruhi profitabilitas (Singapurwoko, 2011). Ketika proposi kebijakan hutang tidak diperhatikan perusahaan, maka akan menyebabkan turunnya tingkat profitabilitas suatu perusahaan.

Juniarti \& Evelina (2014) meneliti pengaruh family control, size, sales growth, leverage terhadap profitabilitas. Hasilnya menunjukkan leverage memiliki pengaruh positif signifikan terhadap profitabilitas. Oleh karena itu, maka hipotesis ketiga pada penelitian ini adalah:

$\mathrm{H}_{3}$ : Kebijakan Hutang berpengaruh terhadap profitabilitas perusahaan

Berdasarkan uraian kajian teori, kajian literatur, dan pengembangan hipotesis yang telah dijelaskan sebelumnya, maka model penelitian dapat terlihat pada Gambar 1: 


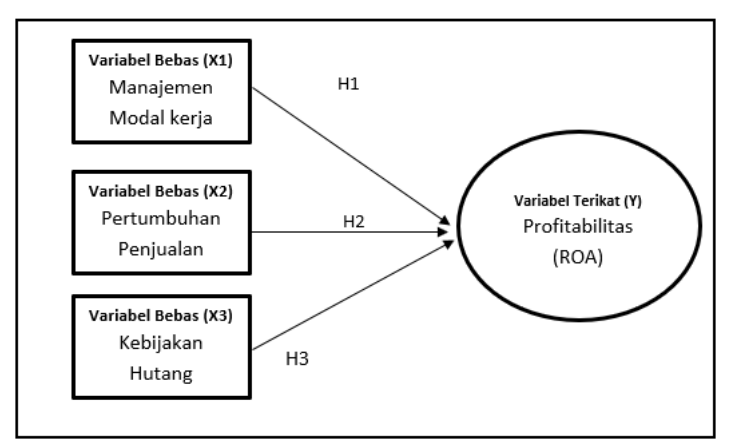

Gambar 1 Model Penelitian

Sumber: Data Diolah Sendiri, 2019.

\section{METODE PENELITIAN}

\subsection{Populasi dan Sampel}

Penelitian ini menggunakan data audited annual report perusahaan yang listed di BEI tahun 2013-2017 yang diperoleh dari laman www.idx.co.id pada perusahaan properti dan real estate. Teknik penarikan sampel yang digunakan adalah non-probability sampling dengan metode purposive sampling. Kriteria penarikan sampel: (1) Perusahaan sektor properti dan real estate yang listed di BEI 2013 - 2017, tidak mengalami Initial Public Offering (IPO), delisting, dan pindah ke sektor non manufaktur selama periode penelitian; (2) Menggunakan satuan mata uang Rupiah; (3) ROA tidak menunjukan nilai negatif.

\subsection{Operasional \\ Pengukuran}

Variabel

dan

\subsubsection{Profitabilitas}

Variabel dependen dalam penelitian ini adalah profitabilitas (Y) yang diukur menggunakan ROA (Return on Assets).

$$
\text { Return on Asset }=\frac{\text { Laba Bersih Setelah Pajak }}{\text { Total Aktiva }} \times 100 \%
$$

Sumber : Kieso et al. (2010)

\subsubsection{Manajemen Modal Kerja}

Variabel manajemen modal kerja pada penelitian ini dikuru menggunakan rasio keuangan perputaran modal kerja. Rasio ini mengukur apakah modal kerja dari sebuah perusahaan dalam periode tertentu sudah efektif atau belum dalam membiayai kegiatan operasional perusahaannya.
Perhitungan rasio keuangan ini dapat dirumuskan sebagai berikut:

Perputaran Modal Kerja $=\frac{\text { Penjualan Bersih }}{\text { Modal Kerja Bersih }} \times 100 \%$

Sumber: Munawir (2014)

\subsubsection{Pertumbuhan Penjualan}

Pertumbuhan penjualan perusahaan diukur dengan rasio pertumbuhan penjualan. Adapaun rasio keuangan tersebut dirumuskan sebagai berikut:

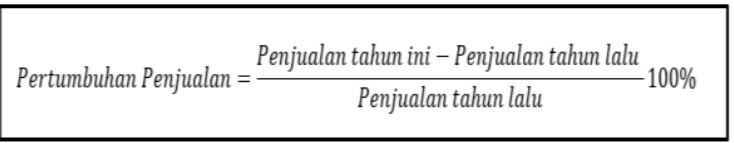

Sumber : Munawir (2014)

\subsubsection{Kebijakan Hutang}

Variabel kebijakan hutang pada penelitian diukur menggunakan Debt to Asset Ratio Perhitungan rasio keuangan ini dapat dirumuskan sebagai berikut:

$$
\text { Debt to Assets Ratio }=\frac{\text { Total Liabilitas }}{\text { Total Aset }}
$$

Sumber: Munawir (2014)

\subsection{Teknik Pengolahan dan Analisis Data}

Penelitian ini diolah menggunakan aplikasi statistik Eviews 9 untuk melakukan. Analisis data dilakukan dengan analisis statistik deskriptif, penentuan model estimasi (uji chow, uji hausman, dan uji langrange multiplier), uji asumsi klasik (uji multikolinearitas, uji heteroskedastisitas), dan uji hipotesis (analisis reg resi data panel, koefisien determinasi, dan uji t).

Model persamaan regresi data panel yang terbentuk dalam penelitian ini adalah:

ROA $=\alpha+\beta 1$ WORKCAPit + $\beta 2 S A L E S G R O W T H i t+\varepsilon$

Keterangan:

$\mathrm{ROA}=$ Return oniAsset (Profitabilitas)

$\alpha \quad=$ Koefisien Persamaan Regresi

WORKCAP = Working Capital/Modal

Kerja (Perputaran Modal

Kerja)

SALES = Tingkat Penjualan (Perputaran Aset Tetap

$\beta 12=$ Koefisien Regresi

$\varepsilon \quad=$ Error 


\section{HASIL DAN PEMBAHASAN \\ 4.1 Karakteristik Data}

Hasil analisis data berdasarkan kriteria purposive sampling yang telah ditetapkan sebelumnya dapat diketahui bahwa perusahaan yangiimelakukan Initial Public Offering (IPO) selama tahun observasi sebanyak 15 perusahaan. Kriteria selanjutnya yaitu perusahaan yang mengalami delisting dari BEI selama tahun observasi sebanyak 6 perusahaan. Selanjutnya, diketahui tidak ada perusahaan perusahaan yang menyajikan annual report selain mata uang rupiah. Perusahaan yang menunjukan nilai ROA negatif sebanyak 10 perusahaan. Kriteria terakhir yaitu data annual report tidak tersedia lengkap sesuai variabel yang dibutuhkan sebanyak 10 perusahaan. Berdasarkan analisis tersebut, total perusahaan yang memenuhi kriteria yang telah ditetapkan adalah sebanyak 20 perusahaan per tahun. Jumlah observasi keseluruhan selama periode 2013 - 2017 diketahui sebanyak 100 sampel. Jumlah tersebut akan dijadikan sebagai acuan dalam mengukur setiap variabel untuk memperoleh hasil analisis melalui pengujian terhadap hipotesis yang diajukan.

\subsection{Statis tik Deskriptif}

Hasil analisis statistik deskriptif terlihat pada Tabel 1 berikut:

Tabel 1 Statis tik Deskriptif

\begin{tabular}{lrrrr}
\hline Variabel & Mean & Max & Min & $\begin{array}{r}\text { Std.D } \\
\text { ev }\end{array}$ \\
\hline ROA & 0.0638 & 0.2216 & 0.0030 & 0.047 \\
& 33 & 53 & 7 & 20 \\
WCM & 0.2937 & 0.7185 & 0.0082 & 0.191 \\
& 47 & 82 & 65 & 60 \\
GROW & 0.1463 & 2.0417 & 0.8712 & 0.388 \\
TH & 29 & 84 & 40 & 96 \\
& 0.3931 & 0.6915 & 0.0637 & 0.148 \\
LEV & 16 & 36 & 74 & 49 \\
OBSER & & & & \\
VATIO & & & & \\
N & 100 & 100 & 100 & 100 \\
& & & & \\
\hline
\end{tabular}

Sumber: Olah data dengan Eviews 9, 2019.

\subsection{Hasil Pengujian Asumsi Klasik}

Berdasarkan uji multikolinearitas yang mengacu pada Gujarati (2006) dan uji heterokedastisitas yang mengacu pada Ghozali (2016) dapat disimpulkan data pada penelitian ini tidak mengalami permasalahan uji asumsi klasik.

\subsubsection{Uji Chow}

Menurut Basuki \& Prawoto (2016) terdapat 3 model estimasi data panel yaitu common effect, fixed effect, dan random effect. Dalam menentukan model estimasi terbaik antara common effect dan fixed effect maka dilakukan uji chow. Adapun hasil pengujian ini terlihat pada Tabel 2 berikut:

Tabel 2 Hasil Uji Chow

\begin{tabular}{lccc}
\hline Effects Test & Statistic & d.f. & Prob. \\
\hline Cross-section & & & \\
F & 5.072341 & $(19.77)$ & 0.0000 \\
\hline \hline
\end{tabular}

Sumber: Olah data dengan Eviews

Berdasarkan tabel 2 nilai Prob. Crosssection $F$ lebih besar dari alpha 5\% (0,000 $>0,05)$ yang artinya model estimasi terbaik adalah fixed effect.

\subsubsection{Uji Hausman}

Uuji husman digunakan untuk menentukan model estimasi terbaik antara fixed effect dan random. Adapun hasil pengujian ini terlihat pada tabel 3 sebagai berikut:

Tabel 3. Hasil Hausman

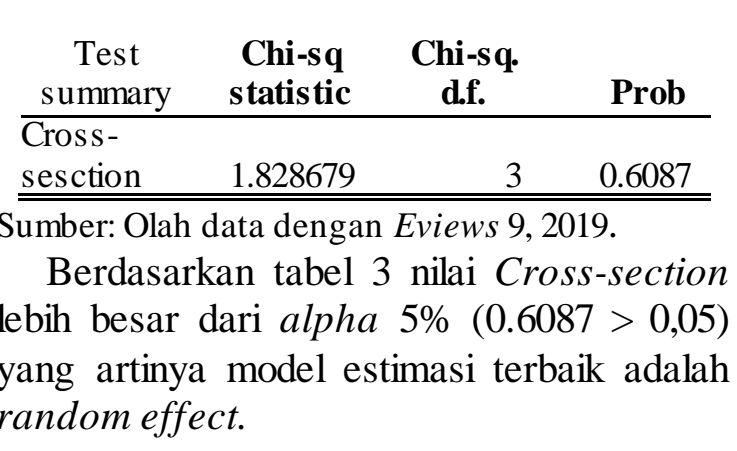

\subsubsection{Uji Langrange Multiplier}

Uji LM ini dilakukan untuk menentukan model estimasi terbaik antara common effect dan random effect. Adapun hasil pengujian terlihat pada tabel 4 berikut:

\section{Tabel 4 Hasil Langrange Multiplier}

\begin{tabular}{cccc}
\hline \multicolumn{3}{c}{ Test Hypothesis } \\
$\begin{array}{c}\text { Test } \\
\text { summary }\end{array}$ & $\begin{array}{c}\text { Cross- } \\
\text { section }\end{array}$ & Time & Both \\
\hline Breusch- & $(0.0000)$ & & $(0.0000)$ \\
\hline \hline
\end{tabular}


Pagan (0.2210)

Sumber: Olah data dengan Eviews 9, 2019.

\subsection{Hasil Pengujian Hipotes is}

\subsubsection{Hasil Regresi Data Panel}

Adapun paparan hasil regresi dengan data panel menggunakan model terbaik random effect terlihat pada tabel 5 sebagai berikut:

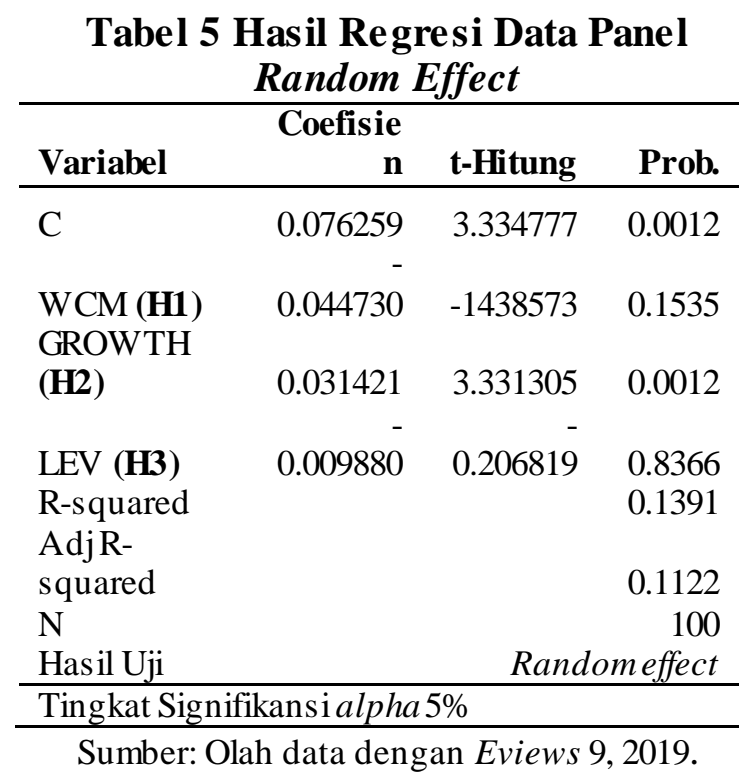

Sesuai dengan paparan hasil regresi pada tabel 5, maka model persamaan regresi data panel yaitu:

$$
\begin{aligned}
\mathrm{ROA}_{\mathrm{it}}= & 0.076259-0.044730 \mathrm{WCM}_{\mathrm{it}}+ \\
& 0.031421 \mathrm{GROWTH}_{\mathrm{it}}- \\
& 0.009880 \mathrm{LEV}_{\mathrm{it}}
\end{aligned}
$$

\subsubsection{Hasil Koefisien Determinasi}

Koefisien determinasi $\left(\mathrm{R}^{2}\right)$ digunakan untuk mengukur sejauh mana suatu model mampu menjelaskan variasi dari variabel independen pada penelitian ini. Tabel 5 menyajikan nilai dari koefisien determinasi yang terdiri dari $\mathrm{R}^{2}$ sebesar 0.1391 dan adjusted $\mathrm{R}^{2}$ sebesar 0.1122 . Menurut Ghozali (2016) nilai koefisien determinasi untuk data yang menggunakan lebih dari 2 variabel independen dapat dilihat pada nilai adjusted $\mathrm{R}^{2}$, Nilai adjusted $\mathrm{R}^{2}$ tersebut menunjukkan bahwa variabel manajemen moda kerja, pertumbuhan penjualan dan kebijakan hutang mampu menjelaskan variabel profitabilitas sebesar $11 \%$ sedangkan $89 \%$ dijelaskan oleh variabel lain.

\subsubsection{Analisis Data}

Berikut adalah tabel ringkasan hasil uji

\begin{tabular}{|c|c|c|c|c|}
\hline & Hipotesis & Sig. & Koef & Hasil \\
\hline $\mathrm{H} 1$ & $\begin{array}{l}\text { Terdapat } \\
\text { pengaruh } \\
\text { manajemen modal } \\
\text { kerja terhadap } \\
\text { profitabilitas }\end{array}$ & $\begin{array}{l}0.15 \\
35\end{array}$ & $\begin{array}{l}- \\
0,04473\end{array}$ & $\begin{array}{c}\text { Tidak } \\
\text { Terdukung }\end{array}$ \\
\hline $\mathrm{H} 2$ & $\begin{array}{l}\text { Terdapat } \\
\text { pengaruh } \\
\text { pertumbuhan } \\
\text { penjualan } \\
\text { terhadap } \\
\text { profitabilitas }\end{array}$ & $\begin{array}{l}0.00 \\
12\end{array}$ & 0,03142 & Terdukung \\
\hline $\mathrm{H} 3$ & $\begin{array}{l}\text { Terdapat } \\
\text { pengaruh } \\
\text { kebijakan hutang } \\
\text { terhadap } \\
\text { profitabilitas }\end{array}$ & $\begin{array}{l}0.83 \\
66\end{array}$ & $\begin{array}{l}- \\
0,00988\end{array}$ & $\begin{array}{c}\text { Tidak } \\
\text { Terdukung }\end{array}$ \\
\hline
\end{tabular}
dari penelitian :

Tabel 6 Ringkasan Hasil Uji

\section{Pengaruh Manaje men Modal Kerja Terhadap Profitabilitas}

Tabel 6 menunjukkan bahwa hipotesis 1 tidak terdukung, yang berarti bahwa manajemen modal kerja tidak memiliki pengaruh terhadap profitabilitas perusahaan. Hasil ini diperkuat oleh Martien (2016) yang menunjukkan tidak adanya pengaruh manajemen modal kerja yang diukur melalui perputaran modal kerja terhadap profitabilitas. Hasil yang sama diperkuat oleh Meidiyustiani (2016) yang juga menyatakan tidak adanya pengaruh modal kerja perusahaan terhadap profitabilitas. Hasil penelitian ini bertentangan dengan penelitian Iskandar, et al. (2014), Nengsy (2015), Bulan (2016), Sapetu, et al. (2017) yang menyatakan bahwa manajemen modal kerja berpengaruh terhadap profitabilitas.

Sebuah perusahaan sangat membutuhkan modal kerja demi mendukung kegiatan atau aktivitas operasional ketika menghadapi peningkatan penjualan. Menurut Meidiyustiani (2016) tingkat fluktuasiidalam penjualan disebabkan oleh faktor musiman dan siklus yang dapat mempengaruhi kebutuhan modal kerja. berdasarkan teori pecking 
order perusahaan harus menentukan prioritas para manajer dalam menentukan pendanaannya dan urutan yang dijadikan prioritas adalah internal fund (dana internal), debt (hutang), dan equity (ekuitas). Pada penelitian ini manajemen modal kerja tidak berpengaruh terhadap profitabilitas di karenakan pengelolaan modal kerja yang kurang efektif. Akibat dari kondisi ini ialah penjualan yang ada pada suatu perusahaan menjadi berkurang atau mengalami penurunan. Ketika penjualan mengalami penurunan yang cukup signifikan, maka akan mengakibatkan profitabilitas yang diperoleh perusahaan tidak maksimal atau tidak mengalami peningkatan.

\section{Pengaruh Pertumbuhan Penjualan Terhadap Profitabilitas}

Tabel 6 menunjukkan bahwa hipotesis 2 terdukung, yang berarti bahwa pertumbuhan penjualan berpengaruh terhadap profitabilitas perusahaan. Hasil ini diperkuat oleh Hasanah \& Enggariyanto (2018), Chotimah \& Susilowibowo (2014), dan Shintya, et al. (2017) yang menyatakan terdapat perngaruh antara pertumbuhan penjualan dan profitabilitas. Hasil penelitian ini tidak sejalan dengan penelitian Sari, et al. (2014), Rifai, et al. (2015), Putra \& Badjra (2015), Meidiyustiani (2016) menyatakan tidak terdapat pengaruh antara pertumbuhan penjualan dan profitabilitas.

Indikasi variabel pertumbuhan penjualan yang memiliki pengaruh terhadap profitabilitas dapat dilihat melalui kontribusi pada tingkat penjualan yang diperoleh perusahaan dari tahun ke tahun. Jika perusahaan meningkatkan pertumbuhan penjualan dengan menggunakan aset dan sumber daya secara optimal, berarti perusahaan tersebut mampu membentengi posisi ekonomi untuk kelangsungan hidupnya. Hal ini mengakibatkan profitabilitas yang dihasilkan perusahaan akan semakin tinggi. Semakin tinggi penjualan perusahaan, maka semakin baik kinerja yang diperoleh oleh perusahaan tersebut (Shintya, et al,. 2017). Ketika kinerja perusahaan dikategorikan baik maka nilai dari profitabilitas perusahaan juga dapat dikatakan baik, hal ini menunjukkan bahwa pertumbuhan penjualan berpengaruh terhadap profitabilitas.

\section{Pengaruh Kebijakan Hutang Terhadap Profitabilitas}

Tabel 6 menunjukkan bahwa hipotesis 3 tidak terdukung, yang berarti bahwa kebijakan hutang tidak berpengaruh terhadap profitabilitas perusahaan. Hasil ini diperkuat oleh Hansen \& Juniarti (2014) yang memaparkan tidak adanya pengaruh kebijakan hutang terhadap profitabilitas. Hasil penelitian ini bertentangan dengan penelitian Gunde, Murni, \& Rogi, (2017), Putra \& Badjra, (2015), Sapetu, et al. (2017), Shintya, Situmorang, \& Iryani, (2017), Juniarti \& Evelina , (2014) yang menyatakan bahwa terdapat pengaruh antara kebijakan hutang dan profitabilitas.

Indikasi tidak adanya pengaruh variabel kebijakan hutang (leverage) terhadap profitabilitas dengan proxy ROA dikarenakan tidak adanya perubahan yang signifikan terhadap tingkat profitabilitas perusahaan meskipun tingkat hutangiperusahaan naik dan turun. Bedasarkan teori stakeholder pada penelitian ini pemegang saham sbagai stakeholernya, pemegang saham menginginkan profitabilitas tinggi dari perusahaan, dan secara tidak langsung perusahaan akan menerapkan kebijakan salah satunya dengan pengelolaan kebijakan hutang. Hal lain dikarenakan ketika perusahaan berhutang maka perusahaan akan membayarkan beban bunga, beban bunga adalah satu komponen pengurang laba yang artinya perusahaan harus membayar beban bunga yang mengakibatkan tingkat profitabilitas rendah. Berdasarkan asumsi tersebut maka disimpulkan bahwa kebijakan hutang tidak memiliki pengaruh terhadap profitabilitas. 


\section{KESIMPULAN, KETERBATASAN DAN SARAN \\ 5.1 Kesimpulan}

Berdasarkan hasil pengujian yang telah diuraikan sebelumnya, maka dapat ditarik kesimpulan yaitu : (1) Manajemen modal kerja tidak memiliki pengaruh terhadap profitabilitas perusahaan; (2) Pertumbuhan penjualan memiliki pengaruh terhadap profitabilitas perusahaan; (3) Kebijakan hutang tidak memiliki pengaruh terhadap profitabilitas perusahaan.

\subsection{Keterbatasan}

Adapun keterbatasan yang dapat berguna bagi pengembangan penelitian sejenis, seperti: (1) Sampel penelitian terbatas pada perusahaan sektor properti dan real estate yang terdaftar di BEI sehingga belum mewakili seluruh perusahaan yang terdaftar; (2) Periode yang digunakan terbatas pada time horizon selama 5 tahun yaitu 2013 - 2017; (3) Pengukuran variabel dependen profitabilitas menggunakan satu proksi saja yaitu return on asset (ROA); (4) Pengukuran variabel independen manajemen modal kerja menggunakan satu proksi saja yaitu perputaran modal kerja.

\subsection{Saran}

Berdasarkan pada keterbatasan yang telah diuraikan, maka saran untuk penelitian selanjutnya adalah; (1) Penelitian selanjutnya diharapkan agar dapat menambah jumlah sampel observasi, tidak hanya menggunakan sektor perusahaan properti dan real estate, namun menggunakan seluruh sektor perusahaan di BEI agar hasil penelitian dapat mewakili seluruh perusahaan; (2) Menambah jumlah periode yang digunakan sehingga dapat menghasilkan jumlah sampel yang lebih banyak dan dapat mewakili tahun-tahun sebelumnya; (3) Menggunakan proksi selain return on asset (ROA) seperti return on equity (ROE), return on Invesment (ROI) dan net profit margin (NPM); (4) Penelitiannya selanjutnya dapat menambah proksi lain yang wakili variabel manajemen modal kerja seperti perputaran piutang perputaran kas, dan perputaran persediaan.

\section{DAFTAR PUSTAKA}

Arif, S., Hidayat, R. R., \& Zahroh, Z. (2015). Pengaruh Perputaran Modal Kerja, Leverage Dan Pertumbuhan Penjualan Terhadap Profitabilitas (Studi pada Perusahaan Makanan dan Minuman yang Terdaftardi Bursa Efek Indonesia pada Tahun 2011-2013). Jurnal Administrasi Bisnis (JAB), 27(1), 1-9.

Bulan, T. P. (2015). Pengaruh Modal Kerja terhadap Tingkat Profitabilitas pada PT Adira Dinamika Multi Finance Tbk. Jurnal Manajemen Dan Keuangan, 4(1), 305-316.

Chotimah, C., \& Susilowibowo, J. (2014, April). Pengaruh Struktur Modal, Modal Kerja Dan Pertumbuhan Penjualan Terhadap Profitabilitas. Jurnal Ilmu Manajemen, 2(2), 422433.

Evelina, \& Juniarti. (2014). Pengaruh family control, Size, Sales Growth, Leverage Terhadap Profitabilitas Dan Nilai Perusahaan keuangan. Business Accounting Review, 2(1), 31-38.

Ghozalo, I. (2016). Aplikasi Analisis Multivarite dengan Program IBM SPSS 23.

Gujarati, D. (2006). Ekonometrika Dasar. Jakarta: Erlangga.

Gunde, Y. M., Murni, S., \& Rogi, M. H. (2017, September). Analisis Pengaruh Leverage Terhadap Profitabilitas Pada Perusahaan Manufaktur Sub Industri Food And Beverages Yang Terdaftar di BEI (Periode 2012-2015). Jurnal EMBA, 5(3), 4185-4194.

Hansen, V., \& Juniarti. (2014). Pengaruh Family ControlL, Size, Sales Growth, Dan Leverage Terhadap Profitabilitas Dan Nilai Perusahaan Pada Sektor Perdagangan, Jasa, Dan 
Investasi. Business Accounting Review, 2(1), 121-130.

Hasanah, A., \& Enggariyanto, D. (2018).

Analisis Faktor-Faktor Yang

Mempengaruhi Return On Asset

PadaPerusahaan Manufaktur yang

Terdaftar Di BursaEfek Indonesia.

Journal of Applied Managerial

Accounting, 2.1, 15-25

Hasibuan, V., Dzulkirom AR, M., \& Endang NP, N. (2016). Pengaruh Leverage dan Profitabilitas Terhadap Nilai Perusahaan (Studi pada Perusahaan Property dan Real Estate yang Terdaftar di Bursa Efek Indonesia Periode Tahun 20122015). Jurnal Administrasi Bisnis, 39(1), 139-147.

Irawati, c. (n.d.). Analisis Efisiensi Modal Kerja, Likuiditas Dan Leverage Serta Pengaruhnya Terhadap Profitabilitas (Studi Kasus Pada Perusahaan Manufaktur yang Listing di Bursa Efek Indonesia Tahun 2013-2015).

Iskandar, T., DP, E. N., \& Darlis, E. (2014). Pengaruh Perputaran Modal Kerja, Struktur Modal Dan Likuiditas Terhadap Likuiditas Terhadap di Bursa Efek Indonesia. JOM FEKON, 1(2), 1-15.

Martien, E. (2016, Oktober). Efektivitas Penggunaan Modal Kerja Dan Likuiditas Terhadap Rentabilitas Pada PT multi Indocitra, Tbk. Dan Entitas Anak. Jurnal FinAcc, 1(6).

Meidiyustiani, R. (2016, Oktober). Pengaruh Modal Kerja, Ukuran Perusahaan, Pertumbuhan Penjualan Dan Likuiditas Terhadap Profitabilitas Pada Perusahaan Manufaktur Sektor Industri Barang Konsumsi Yang Terdaftar Di Bursa Efek Indonesia (BEI) Periode Tahun 2010-2014. Jurnal Akuntansi dan Keuangan, 5(2), 41-59.

Nengsy, H. (2015, Desember). Pengaruh Perputaran Modal Kerja Dan Perputaran Piutang Terhadap Profitabilitas Pada Perusahaan
Manufaktur yang Terdaftar Di Bursa Efek Indonesia. Jurnal Akuntansi dan Keuangan, 4(2), 2089-6255.

Pagano, P., \& Schivardi, F. (2000, Oktober). Firm Size Distribution and Growth.

Putra, A. W., \& Badjra, I. B. (2015). Pengaruh Leverage, Pertumbuhan Penjualan Dan Ukuran Perusahaan Terhadap Profitabilitas. E-Jurnal Manajemen Unud, 4(7), 2052-2067.

Rahmawati, S., Salim, M., \& ABS, M. (2018). Pengaruh Likuiditas, Pertumbuhan Penjualan, Perputaran Modal Kerja, Ukuran Perusahaan Dan Leverage Terhadap Profitabilitas Perusahaan (Studi pada Perusahaan Manufaktur yang Terdaftar pada BEI pada Tahun 2014 - 2016). e- Jurnal Riset Manajemen Prodi Manajemen, 93107.

Rifai, M., Ariyanti, R., \& Magdalena, M. (2015). Pengaruh Ukuran Perusahaan, Struktur Modal dan Pertumbuhan Penjualan Terhadap Profitabilitas Studi Pada Perusahaan Manufaktur Di BEI Tahun 20102012.

Santhi, I. P., \& Dewi, S. K. (n.d.). Pengaruh Manajemen Modal Kerja Terhadap Tingkat Profitabilitas Pada Perusahaan Makanan Dan Minuman Yang Terdaftar Di Bursa Efek Indonesia Periode 2010-2013. 35223539.

Santoso, C. (2013, Desember). Perputaran Modal Kerja Dan Perputaran Piutang Pengaruhnya Terhadap Profitabilitas Pada PT. Pegadaian (Persero). 1(4), 1581-1590.

Sapetu, Y., Saerang, I., \& Soepeno, D. (2017, Juni). Pengaruh Manajemen Modal Kerja Terhadap Profitabilitas Perusahaan (Studi kasus pada perusahaan food and beverages yang terdaftar di Bursa Efek Indonesia periode 2012-2015). Jurnal EMBA, 5(2), 1440-1451. 
Sari, F. N., Ritonga, K., \& Azlina, N. (2014, Oktober). Pengaruh Manajemen Modal Kerja Terhadap Profitabilitas Perusahaan (Studi kasus pada perusahaan food and beverages yang terdaftar di Bursa Efek Indonesia periode 2010-2012). JOM FEKON, 1(2), 1-15.

Sitorus, Y. S., \& Irustami. (2013). Analisis Pengaruh Manajemen Modal Kerja Terhadap Profitabilitas (Studi Kasus Pada Perusahaan Properti dan Real Estate yang Go Public di BEI Tahun 2006 - 2011).

Sufiana, N., \& Purnawati, N. (2013, April). Pengaruh Perputaran Kas, Perputaran Piutang Perputaran Persediaan Terhadap Profitabilitas. E-Jurnal Manajemen, 2(4), 451467.

Supriadi, Y., \& Fazriani, F. (2011, April). Pengaruh Modal Kerja Terhadap Tingkat Likuiditas Dan Profitabilitas (Studi Kasus Pada PT Timah, Tbk. Dan PT Antam, Tbk). Jurnal Ilmiah Ranggagading, 11(1), $1-11$.

Supriadi, Y., \& Puspitasari, R. (2012, April). Pengaruh Modal Kerja Terhadap Penjualan Dan Profitabilitas Perusahaan Pada PT Indocement Tunggal Prakarsa TBK. Jurnal Ilmiah Kesatuan, 1(14), 7179.

Sutapa, \& Setyawan, H. (2008, Januari). Pengujian Pecking Order Theory Pada Emiten Syariah Di Bursa Efek Indonesia. Jurnal Keuangan dan Perbankan, 12(1), 22-28.

Syaputra, H., \& Ibrahim, M. (2018). Pengaruh Modal Kerja Terhadap Profitabilitas Perusahaan Sektor Advertising Printing Media Yang Printing Media Yang Terdaftar Di Bursa Efek Indonesia. JOM FISIP, 2(1), 1-15.

Utami, M. S., \& Dewi S, M. R. (2016). Pengaruh Manajemen Modal Kerja Terhadap Profitabilitas Perusahaan Manufaktur Yang Terdaftar Di
Bursa Efek Indonesia. E-Jurnal Manajemen Unud, 5(6), 3476-3503. 